\title{
The Early Study of Misconsepsi Materials and Transfer of Class Viid SMP Negeri 1 Wonosalam Demak
}

\author{
Isna Lukluil Millah", Suharto Linuwih ${ }^{2}$, Siti Wahyuni ${ }^{3}$, Ahmadun $^{4}$ \\ ${ }^{1,2}$ Physics Education, Graduate School, Universitas Negeri Semarang, Indonesia \\ ${ }^{3}$ SMP N 1 Wonosalam Demak, Demak, Indoneisa \\ ${ }^{4}$ MTs N 3 Demak, Buyaran Guntur, Indonesia \\ Corresponding email: sabiqakhisna@gmail.com
}

\begin{abstract}
The purpose of this study was to identify the initial misconceptions of heat and its displacement in grade VIID students of SMP Negeri 1 Wonosalam Demak. The method used in this study by using the instrument of pretest. Research objectives: 1). To know the early study of misconception of matter of heat and its transfer to students of SMP Negeri 1 Wonosalam Demak, 2). Knowing the effectiveness of the use of tier tree misconceptions The method is done by instrument test, pretest. The greatest pretest result of students experiencing misconceptions is $60.7 \%$. indicator of determining the final temperature, determining the heat of the species, determining the heat capacity, determining the amount of heat based on the graph and the black principle of students experiencing misconceptions in the sub-chapters type.
\end{abstract}

Keyword: Misconception, Tree Tier Test, heat and its displacement.

\section{Introduction}

Physics is one of the subjects in science that can develop an inductive analytical thinking ability to solve problems and relate to qualitative and quantitative natural events using mathematics (MoNE, 2003). In line with the definition issued by the Ministry of National Education, some researchers put the core of physics on the problem of natural phenomena, among them Lestari and Linuwih (2014), Azizah, et. al. (2014) and Lebdiana, et. al. (2015).

As for Yuliono, et. al. (2014) state that the subject of physics is a lesson that is not far from the problem of concept, conceptual understanding, and mathematical problem solving. Of course, the learning process is not just a mastery of a collection of knowledge in the form of facts, concepts, or principles alone, but also a process of discovery. One of the learning activities in the scientific field is physics (Ningrum \& Linuwih, 2015)

The subjects of physics, biology, and chemistry in Junior High School enter into one category of Science of Natural Science (IPA), in the applicable curriculum referred to as Integrated Science. In the 2013 curriculum Integrated IPA has $5 \mathrm{JP}$ in each week. One of the materials in IPA Integrated class VII is heat and its displacement. Heat is one of the material of physics that requires a deep explanation because it closely related to student life.
Setyadi's research (2012) reported that students have misconceptions on the concept of temperature and heat of $63.7 \%$ included in the criteria of high misconception. One of the factors causing low level of mastery and misconception level is high criteria because students are not prepared to answer these questions, it proves that in the minds of students there is a concept of temperature and heat but it is possible that it is wrong so that in answering the problem with the reason is that students answer as much as they can.

Some other researchers have found that temperature and heat, according to students are the same thing (Alwan (2011), Suparno (2013), Alfiani (2015), and Silung (2015)). Another study records students' thinking that the temperature of an object depends on the mass or mass of the object, ie the greater the mass of an object the greater its temperature, and vice versa (Suparno, 2013); the temperature of the object continues to increase when it undergoes a change of form (Suparno, 2013, Hafizah et al, 2014; Maunah et al, 2014; Alfiani, 2015), and the idea that the smaller the mass of an object the greater the heat is absorbed so the temperature rises rapidly (Silung, 2015 ).

Setiawan and Linuwih (2010) revealed that in the minds of students there is actually a conception of various things about physics, but the conception is not well ordered. Conception is the individual interpretation of a concept of science (Berg, 1991). 
As for the cause of misconception is the initial knowledge and factual knowledge of the students are less excavated resulting in the basic concept of having an error. In addition, students' reasoning is wrong due to lack of information about the concept in other words incomplete reasoning. Another factor is the use of lecture methods that do not provide students the opportunity to prove the concept described both in the form of real and artificial forms (Suparno, 2013). One attempt to correct student misconceptions is to remediate. According Sutrisno, et. al. (2007), remediation is a process to help students overcome learning difficulties, especially overcomes misconceptions. One very useful way of teaching to overcome misconceptions, is not difficult to apply, and has great potential is demonstration (Berg, 1991).

Further Berg explained that the demonstration is a trial run by the teacher (alone or with the help of some students in front of the class). In line with that, Roestiyah (2012) states that the demonstration is a model of teaching an instructor or teacher by showing or showing the course of a process so that all students in the class can see and observe the process shown by the teacher.

Media is any person, material, tool, or event that can create conditions that enable learners to receive knowledge, skills and attitudes. Based on this understanding can be said that teachers, textbooks, and environment is an example of a media. Each media is a means to go to a destination and inside it contain information that can be communicated to others. The information may be obtained from books, recordings, internet, movies, microfilm and so on. The supporting software for the development of interactive visual learning media and challenging one of them is the video media macromedia flash. Excess Macromedia flash is able to function as a medium of information presentation in the form of text, graphics, simulation, animation, exercises, quantitative analysis, and direct feedback (Viajayani, 2013).

Learning media is a device that serves to convey information knowledge from source to recipient information. The method is a deliberate procedure designed to help students learn better in achieving learning objectives. Of course, in addition to teaching methods, learning media plays an important role in learning. These two elements are interrelated. The use of learning media in the learning process can generate new desires and interests, generate motivation and stimulation of learning activities, and even bring psychological influences on learners.

SMP Negeri 1 Wonosalam is one of the high schools in Wonosalam sub-district of Demak district, which comes from various students of lower-middle-income category compared to some other schools. In addition, this can be seen from the average score of the national exam score of science subjects in 2017 is still below the average value of the district. This result is thought to have something to do with children not understanding or even experiencing misconceptions. The allegation is reinforced by the experience of researchers when teaching at SMP Negeri 1 Wonosalam Demak for the last 2 years. Visible average class of student re-examination on caloric material and its displacement is 6.5. The value is still categorized less than the value of KKM IPA. Based on the observation, the researchers suspect that there are still students who are not familiar with the concept or even misconception on the matter of heat and its movement. The problem of misconception is an important theme to study. The problem of misconception is a challenge for teachers to create learning that gives students an understanding of the concept of actual thinking. In addition, misconceptions also require teachers to choose methods and learning media so that students are more motivated in the implementation of teaching and learning process.

Class VIID in this study because it is a superior class, students who have been selected by the school and has a relatively equal academic potential. Therefore, in the mastery of the concept, superior class students are expected to have better understanding ability. Based on the description, the researcher is interested to find the description of the concept of remediation of heat materials and their movement in VIID class of SMP Negeri 1 Wonosalam Demak. This research is expected to give thought contribution in the effort to improve misconception in the students as well as to improve the learning achievement. The formulation of the problem in this research are: 1). How is the initial study of misconception of matter of heat and its movement in students of SMP Negeri 1 Wonosalam Demak?, 2). How is the effectiveness of the use of tree tier test in the remediation of misconceptions? The study was conducted by instrument, pree test. 


\section{Methods}

This research was conducted in April 2018 at SMP Negeri 1 Wonosalam Demak. Research subject is class VIID. Implementation stage of the instrument with the validity of the test questions, the reliability of the problem, the level of difficulty of problems and different problems. The pretest result is analyzed by tree tier test.

\section{Result and Discussion}

The following is the result of pretest research with tree tier test as in table 1:

Table 1. Pretest Result

\begin{tabular}{ccccc}
\hline $\begin{array}{c}\text { No } \\
\text { matt } \\
\text { er }\end{array}$ & $\begin{array}{c}\text { Misconce } \\
\text { ption }\end{array}$ & $\begin{array}{c}\text { Predict } \\
\text { ing }\end{array}$ & $\begin{array}{c}\text { Concept } \\
\text { Not } \\
\text { Understan } \\
\text { ding }\end{array}$ & $\begin{array}{c}\text { Conce } \\
\text { pts }\end{array}$ \\
\hline 1 & 1 & 0 & 27 & 0 \\
2 & 12 & 2 & 14 & 0 \\
3 & 13 & 1 & 12 & 2 \\
4 & 15 & 0 & 10 & 3 \\
5 & 17 & 0 & 11 & 0 \\
6 & 12 & 2 & 14 & 0 \\
7 & 13 & 1 & 12 & 2 \\
8 & 15 & 0 & 10 & 3 \\
9 & 17 & 0 & 11 & 0 \\
10 & 12 & 2 & 14 & 0 \\
11 & 13 & 1 & 12 & 2 \\
12 & 15 & 0 & 10 & 3 \\
13 & 17 & 0 & 11 & 0 \\
14 & 12 & 2 & 14 & 0 \\
15 & 13 & 1 & 12 & 2 \\
16 & 15 & 0 & 10 & 3 \\
17 & 12 & 2 & 14 & 0 \\
18 & 13 & 1 & 12 & 2 \\
19 & 15 & 0 & 10 & 3 \\
20 & 17 & 0 & 11 & 0 \\
\hline
\end{tabular}

\section{Conclusion}

Based on the result of the research, it can be concluded that the initial study of misconception of matter of heat and its displacement experienced the highest misconception on the indicator of determining the final temperature, determining the heat of the species, determining the heat capacity, determining the amount of heat based on the graph and the black principle of students experiencing misconceptions in the caloric sub types.

\section{Reference}

Abraham, R.M., Grzybowski, B. E., Renner, W.J., dan Marek, A.E. 1992. Understanding an Misunderstanding of Eight Grades of Five Chemistry Concept in Text Book. Journal of Research in Science Teaching 29 (12): 105-120.

Ahmadi, A., dan Supriyono, W. 2013. Psikologi Belajar. Jakarta: Rineka Cipta.

Alfiani. (2015). Analisis Profil Miskonsepsi dan Konsistensi Konsepsi Siswa SMA pada Topik Suhu dan Kalor. Seminar Nasional Fisika 2015 Jurusan Fisika, Fakultas MIPA, Universitas Negeri Jakarta. SNF2015-IV-29.

Alwan, A. A. (2011). Misconception of Heat and Temperature Among Physics Students. Procedia Social and Behavioral Sciences, (Online), 12: 600-614, (http://sciencedirect.com), diakses 20 Februari 2014.

Dahar, ratna Wilis. 2011. Teori-teori Belajar dan Pembelajaran. Jakarta: Erlangga

Eis, dkk. 2008. Remediasi Miskonsepsi Siswa Menggunakan Mind Scaping Tentang Kalor Di SMP, (Online), (https://repository.uksw.edu/bitstream/.../ 7/T1_202008022_Daftar\% 20 Pustaka. pdf, diakses 19 Oktober 2015.

Euwe Van den Berg, E. (1991). Miskonsepsi Fisika dan Remediasinya. Salatiga: Universitas Kristen Satya Wacana

Hafizah, D., Haris, V., \& Eliwatis. (2014). Analisis Miskonsepsi Siswa Melalui TesMultiple Choice Menggunakan Certainty Of Response Index Pada Mata Pelajaran FisikaMAN 1 Bukittinggi. Edusainstik Jurnal Pendidikan MIPA, 1(1): 100-103.

Hasan, Saleem.Diola Bagayoko., and EllaL Kelley. (1999). Misconceptions and the Certainty of Response Index(CRI). Journal of Physic Education 34(5) 294299.

Hikmat, dkk. 2014. Strategi Konflik Kognitif Berbantuan Media Simulasi Virtual dalam Pembelajaran Fisika Berorientasi Pengubahan Konseptual untuk Meningkatkan Pemahaman Konsep dan menurunkan Kuantitas Siswa yang Miskonsepsi, (online), http://www.univreims.fr/site/evenement/girep-upi-mptl2014-reims internationalconference/gallery_files/site/ 1/90/4491/22908/29321/29329.pdf, diunduh 02 Februari 2016.

Kaltacki, G. D. dan Eryilmaz, A. 2013. A Content Analysis of Physics Textbooks as 
a Probable Source of Misconceptions in Geometric Optics. Hacettepe Universitesi Egitim Fakultesi Dergisi (H. U. Journal of Education) 28(2): 234-245.

K, Eko Setyadi. 2012. Miskonsepsi tentang Suhu dan Kalor pada Siswa Kelas 1 di SMA Muhammmadiyah Purworejo Jawa Tengah, Berkala Fisika Indonesia Volume 1 dan 2.

Lebdiana, R., Sulhadi, N. Hindarto. 2015. Pengembangan Perangkat Pembelajaran Materi Suhu dan Kalor Berbasis Poe (Predict-Observe-Explain) untuk Meremediasi Miskonsepsi Siswa. Unnes Physics Education Journal.UPEJ 4 (2)

Linuwih, Suharto dan Lestari, P.P. 2014. Analisis Konsepsi Dan Perubahan Konseptual Suhu Dan Kalor Pada Siswa Sma Kelas Unggulan

Maunah, Nailul \& Wasis. (2014). Pengembangan Two-Tier Multiple Choice Diagnostic test Untuk Menganalisis Kesulitan Belajar Siswa Kelas X pada Materi Suhu dan Kalor. Jurnal Inovasi Pendidikan Fisika (JIPF), (Online), 3(2): 195-

200 , https://www.scribd.com/doc/225982116/, diakses 18 Oktober 2015

Ningrum, F. S. dan S. Linuwih. 2015. Analisis Pemahaman Siswa SMA Terhadap Fluida Pada Hukum Archimedes. Unnes Physics Education Journal. 4(1): 33-36.

Novak dan Gowin. 1984. Learning how to learn. Cambridge: University Press.

Roestiyah N.K. 2012. Strategi Belajar Mengajar. Jakarta: PT Rineka Cipta

Rusilowati, A. (2008). Profil Kesulitan Belajar Fisika Pokok Bahasan Kelistrikan Siswa Sma Di Kota Semarang. Jurnal Pend. Fisika Indonesia Vol. 4,Halaman 100 No. 2, Juli 2006

Sakti, Indra., Yuniar Mega Puspasari, dan Eko Risdianto. 2012. Pengaruh Model Pembelajaran Langsung (Direct Instruction) melalui Media Animasi Berbasis Macromedia Flash Terhadap Minat Belajar dan Pemahaman Konsep Fisika Siswa di SMA Plus Negeri 7 Kota Bengkulu. Jurnal Exacta, Vol.X No.1 Juni 2012

Setiawan dan S. Linuwih. 2010.The Development Of M-Diagnostic Test To Identify The Understanding Level Of
Junior High School Students In Temperature Subject. Unnes Science Education Journal.

Silung, S.N.W. (2015). Identifikasi Miskonsepsi Siswa SMA pada Materi Suhu dan Kalor serta Kemungkinan Penyebabnya. Prosiding SeminarNasional Jurusan Fisika FMIPA UNESA 2015: 180-185.

Suparno, Paul. 2013. Miskonsepsi dan Perubahan Konsep Dalam Pendidikan Fisika. Jakarta: PT Gramedia Widiasarana Indonesia Grasindo

Suratno, Tatang. 2008. Konstruktivisme, Konsepsi Alternatif dan Perubahan Konseptual dalam Pendidikan IPA. Jurnal Pendidikan Dasar, (10).

Sözbilir, Mustafa. 2003. A Review of Selected Literature on Students' Misconceptions of Heat and Temperature. Boğaziçi University Journal of Education, 20(1): 25-28.

Tayubi, Yuyu R. 2005. Identifikasi Miskonsepsi pada Konsep-konsep Fisika Menggunakan Certainty of Response Index (CRI). Jurnal Mimbar Pendidikan.File UPI. Diakses 19 Oktober 2015.

Tekkaya (2002). Misconceptions as barrier to understanding biology. Journal of Education, 23(259-266)

Viajayani, Eka Reny., Drs Yohanes Radiyono., Dwi Teguh Raharjo, S.Si, M.Si. 2013. Pengembangan Media Pembelajaran Fisika Menggunakan Media Macromedia Flash Pro 8 Pada Pokok Bahasan Suhu dan Kalor. Jurnal Pendidikan Fisika (2013) Vol.1 No.1 halaman 144.

Wijaya, I Komang Wisnu Budi dkk. 2012. Model Demonstrasi Interaktif Berbantuan Multimedia dan Hasil Belajar IPA Aspek Kimia Siswa SMP, (Online), Jurnal Pendidikan dan Pengajaran Jilid 45 Nomor 01 halaman 8898.http://univpendganesha.ac.id/sites/defa ult/files/pengabdian/dra-endangmulyatiningsih-mpd/7c-modelpembelajaran.demonstrasi.pdf, diunduh 13 Desember 2015.

Yuliono, S. N., Sarwanto, \& Wahyuningsih, D. (2014). Video Pembelajaran Berbasis Masalah pada Materi Kalor untuk Siswa Kelas VII. Jurnal Pendidikan Fisika, 2(1),

21-25. 